\title{
The experiences of Vietnamese students in New Zealand: A new country - a new home
}

Hau Trung Ho, Victoria University of Wellington

\begin{abstract}
This study explores the everyday living experiences of five Vietnamese postgraduate students in New Zealand, employing an interpretative phenomenological analysis approach. The analysis revealed one minor theme which captures the students' preparations before coming to New Zealand, and one overarching theme which focuses on living arrangements and circumstances. The students were ill-prepared for their lives in New Zealand, which contributed to the difficulties encountered. They were shocked to find that their studies and lives were affected by accommodation arrangements, which forced them to learn to cope with unfamiliar issues. The overarching essence is that a variety of factors (e.g., familial, cultural, and gender factors) influenced the students' experiences. However, drawing on traditional cultural values, the students could overcome these difficulties. The study has implications for host universities to assist students in coping with the harsh reality of everyday living issues, including having a roof over one's head.
\end{abstract}

\section{Keywords}

Accommodation, international students' experiences, living arrangements, New Zealand, Vietnam 


\section{Introduction}

In recent years, Vietnam has become one of the top sending countries for international students into Western education systems. It is the sixth biggest source country for international students in the U.S.A. (Institute of Intenational Education 2020) and fifth in Canada (Institute of International Education 2020a) in 2019, and fourth in Australia (Australian Education International 2020) in 2020. In New Zealand, Vietnam was ranked $6^{\text {th }}$ in 2019 with 1,270 students (Institute of International Education 2020b). Vietnam is identified as a strategic partner on education by government agencies (Education New Zealand 2018).

For most Vietnamese students, the decision to study overseas is driven by socioeconomic factors, such as the lack of degree programs in certain fields in Vietnam, expectations of better job opportunities after graduation (in Vietnam, the host country, or another country), and students' aspirations to emigrate (Pham 2018).

Studying overseas is both satisfying and challenging. It is an enriching experience for many international students. Lillyman and Bennett (2014), for example, highlight the personal development that takes place, including students' increased levels of confidence, critical thinking, and enhanced career prospects. Others have found that studying abroad may develop students' intercultural competence (Fabricius and Preisler 2015; Schartner 2016). However, students' experiences are not always positive. In leaving their homelands, students lose familiar living environments and support systems (Ward et al. 2001). Many of them face an array of academic and socio-cultural challenges (Marginson et al. 2010; Sawir et al. 2012).

While there is a growing body of research on the experiences of Vietnamese students in other Anglophone countries (Bui 2020; B. T. T. Nguyen and Pennycook 2018; M. N. Nguyen and Robertson 2020), there have been few studies of Vietnamese students' 
experiences in New Zealand (Q. Nguyen and Buckingham 2019; Vu and Doyle 2014). Most studies on international students' experiences in New Zealand have focussed on Chinese students (Ding and Devine 2018; Zhang 2018) or viewed Vietnamese students as a subgroup of Asian students (Campbell 2012; Franken 2013). Whilst Asian students have certain commonalities in their experiences, Asia, especially Southeast Asia, comprises many countries with distinctive cultures and histories. Some of these countries can be depicted as having Confucian heritage cultures. Confucianism has been described as "a system of philosophical, ethical and political thought based on the teachings of Confucius" (Li 1993: 305). Some cultural beliefs are common to cultures partly influenced by Confucianism, rather than suggesting that the countries have the same or shared cultures (Watkins and Biggs 2001). Students' experiences are associated with characteristics and socio-cultural factors of their home countries (Berry 2006), and grouping Vietnamese students in the Asian group potentially "subsumes cultural, historical, linguistic and national difference" (Matthews 2000: 29) amongst students' countries of origins.

Previous research on Vietnamese international students' experiences conducted in other countries offer insights into Vietnamese students' experiences in Western countries, for example, students' self-development (Pham and Saltmarsh 2013), challenges in meeting supervisors' expectations (Nguyen and Pennycook 2018), and the role of social media in students' daily life experience (An et al. 2018). However, there are differences between New Zealand and other Western countries in terms of cultural and national identity (Rinne and Fairweather 2011), which may impact on students' experiences. This can be explained by drawing on the acculturation theory (Berry 2006) in which international students' experiences are linked to several factors in host countries. 


\section{Literature review}

This section briefly reviews the literature on the socio-cultural experiences of international students with a focus on Vietnamese students and identifies the research gap. The theoretical framework of the study is also presented.

\section{Socio-cultural experiences of international students}

The literature highlights the diverse challenges international students may encounter in everyday life, including language difficulties, social interaction, loneliness, homesickness, and accommodation. Language may be associated with a range of issues, for example, poor social interaction and adjustment, local people's stereotyping behaviours, higher cultural stress, and lower level of life satisfaction (Sawir et al. 2012). Similarly, a study on the experiences of Vietnamese students in Australia shows that the students' English competence impacted on their ability to build friendship with locals (Le 2011).

Social connection and interaction are recurrent themes in the literature on international students (Montgomery 2010; Wright and Schartner 2013; Marginson et al. 2010). Montgomery (2010) discovered that international students in her UK study had complex friendship patterns which she described as "a mixture of nationalities". However, most of the students reported that their close friends came from their own countries. A recent cross-cultural study comparing the experiences of Vietnamese students in Singapore and South Korea showed that social media use may influence the students' adaptation in multi-cultural environments (An et al. 2018). Le (2011) indicated reasons for the Vietnamese students' inability to establish friendship with locals including racism, a lack of opportunities for interaction, and the indifference of locals.

Loneliness and homesickness are prevalent amongst international students, resulting from a lack of social support systems and distance from familiar community and environment 
(Sawir et al. 2008). Students coming from countries with dominant collectivistic cultures may feel homesick because they are not prepared for independent living (Khawaja and Stallman 2011). In the same vein, Le (2014) and Tran (2011) found that loneliness, isolation, and homesickness were common among Vietnamese students in Australia.

Past research has focused on the roles language, academic, social and emotional factors play in international student experiences. In recent years, attention is beginning to be placed on accommodation and security issues. Such issues correspond with the lower and foundational levels of Maslow's (1954) hierarchy of needs. Theories of learning and motivation derived from Maslow's hierarchy position the meeting of basic needs for food, shelter, safety and belonging as essential precursors for learning and self-actualisation ( $\underline{\text { Schunk 2012; }}$ Schunk et al. 2012). In terms of international students, accommodation or shelter shapes what constitutes home, security, and belonging in everyday life.

Housing is a crucial physical environmental factor that affects individual mental and general health (World Health Organization 2013). Exploring the experiences of international students in Canada, Calder et al. (2016) emphasize that accommodation costs, which constituted a large percentage of students' living expenses, left them struggling financially. Further, housing issues may result from students' lack of local rental housing market knowledge (Marginson et al. 2010). Despite the importance of living arrangements for the academic and personal wellbeing of international students, little attention has been paid to this topic (Marginson et al. 2010; Arkoudis et al. 2019).

Researchers suggest that housing satisfaction is associated with various factors. Calder et al.'s participants considered privacy, distance to campus, environmental factors, and accommodation for families as criteria for suitable accommodation. Studying the experiences of students in America, Long (2014) points out that students' residential setting may affect 
their social and academic experiences, including academic success, satisfaction, and social integration. Students of different genders and cultural backgrounds may have different attitudes towards privacy and the sharing of living space, and students with good financial resources may have more choice in accommodation, resulting in different levels of satisfaction (Najib et al. 2011). Relationships with flatmates and distance from campus also contribute to housingrelated challenges (Calder et al. 2016).

\section{Theoretical underpinnings of the study}

In keeping with IPA, the study was not grounded in an explicit theoretical framework nor on a set of issues to be investigated. The intention was to capture the essence of the participants' experiences. However, I was aware that the experiences of international students are associated with sociocultural factors in both home and host countries. To explore these factors, I relied on acculturation theory (Berry 2006) and hierarchy of needs (Maslow 1954). Whilst Berry's acculturation theory has been subject to strong critiques (e.g., Ward and Geeraert 2016; Triandis 1997; Lazarus 1997), it shows the general ups and downs of international students' experiences and is useful in theorizing these experiences. Maslow's hierarchy of needs shows the multiple levels of human motivations in the form of a pyramid with physiological (food, water, shelter) needing to be met first, followed by safety and security. Without these needs being met, people struggle to address their higher-level needs. These two theories loosely provided the topics to be explored in the interviews. In-depth semi-structured interviews and IPA's analytic framework allowed for the emergence of new insights and themes related to the student experiences.

\section{The study}

Interpretative Phenomenological Analysis (IPA) (Smith and Osborn 2008) was used to explore the living experiences of Vietnamese students in New Zealand. IPA is a qualitative research approach in which researchers study participants' lived experiences. In using IPA, I 
sought to understand individuals' experiences from their viewpoints and capture the meanings such experiences hold for them.

Each participant was interviewed three times over the year of their time in New Zealand. The semi-structured interviews were in Vietnamese to enable the participants to express themselves in greater depth. Interviews were audio-recorded and transcribed in Vietnamese.

\section{Sample}

IPA requires purposive sampling which involves choosing a relatively homogenous group of participants to identify and capture the shared essence of individual experiences within a particular group (Smith et al. 2009). Participants were recruited through different channels and strategies, such as university notice boards, personal networks, and snowballing. Pseudonyms are used in reporting the findings.

The participants were five Vietnamese Master's students from one New Zealand university and had been in the country for at least six months. This enabled me to explore the changing and diverse aspects of their experiences. The participants were not accompanied by families and had limited overseas experience. Bao's husband and children remained in Vietnam, as did Hai's wife. Four participants were teachers in Vietnam, and one was an official in a government-owned company. The following table summarises the participants' demographics and information.

Table 1. Profiles of the participants

\begin{tabular}{lllll}
\hline Pseudonym & Gender & Field of study & Marital status & Funding \\
\hline Lan & Female & TESOL & Single & Self and family \\
Bao & Female & TESOL & Married & Self \\
Thanh & Female & TESOL & Single & Self and family \\
My & Female & TESOL & Single & Scholarship \\
Hai & Male & Political Science & Married & Scholarship \\
\hline
\end{tabular}


Table 2 presents the students' living situation changes, with a focus on their flatmates:

Table 2. Living situation changes of the students

\begin{tabular}{|l|l|l|l|}
\hline & \multicolumn{3}{|c|}{ Living situation } \\
\cline { 2 - 4 } & Time 1 & Time 2 & Time 3 \\
\hline Lan & Lived with 4 Vietnamese friends throughout the time in New Zealand \\
\hline Bao & Lived with 4 Vietnamese friends throughout the time in New Zealand \\
\hline Thanh & $\begin{array}{l}\text { Vietnamese and New Zealand } \\
\text { flatmates (a couple) }\end{array}$ & $\begin{array}{l}\text { 1 Vietnamese landlady and 1 } \\
\text { Vietnamese flatmate }\end{array}$ & 3Vietnamese classmates \\
\hline My & 3 Vietnamese and 1 English flatmate & $\begin{array}{l}\text { 5 New Zealand and 1 English } \\
\text { flatmate }\end{array}$ & $\begin{array}{l}\text { A Vietnamese family } \\
\text { (parents and child) }\end{array}$ \\
\hline Hai & $\begin{array}{l}\text { A Vietnamese family (parents } \\
\text { and child) }\end{array}$ &
\end{tabular}

As illustrated in Table 2, three of the students (Thanh, My, and Hai) changed their accommodation more than once over the year. Their reasons included the desire to flat with their Vietnamese friends, to be nearer to campus, and/or more affordable accommodation.

\section{Data analysis and findings}

Data were analyzed thematically following the analytical procedures proposed by Smith and colleagues (2009). Transcripts were first analyzed in Vietnamese, with themes and quotations translated into English for reporting purposes. The analysis revealed one overarching theme which involves living arrangements and circumstances. A minor but related theme involves the students' preparation for living in New Zealand. This section begins with the minor theme and then moves on to the overarching one.

\section{"I hadn't thought much. Issues just arose after I came here."}

This theme captures the students' preparations before coming to New Zealand. In their stories, there was a sense of not being aware of how life in a new country would be different. When asked about how they prepared for their lives in New Zealand, the students reported that they started their travels hastily and had not thought about difficulties they might encounter or the differences between life in Vietnam and New Zealand. 
Hai was not even aware of geographical differences between the two countries. He soon realized and experienced the differences:

Initially, I thought New Zealand was like Ha Noi. I didn't think it [New Zealand] is a mountainous region. When I first came here, I rented a flat far from the university. I walked to university and was exhausted. Our university is at the top of the hill. Going up the hill was tiring. After that, I took the bus and started to feel better. (Hai)

The students prepared themselves for study-related issues and neglected potential daily living issues:

I have never thought about that. I only thought that I came here to study. I would have international friends and lecturers and do assignments. That's all. (Thanh)

When I prepared to study abroad, I was just concerned about how teaching and learning styles [in New Zealand] were different. I hadn't thought much. Issues just arose after I came here. (Lan)

In Vietnam, the students worked through their university and an agent connected with the university. This agent assisted the students with their visa applications and provided them with information about New Zealand culture, teaching, and learning. However, while the students were concerned about accommodation, little help was offered. They just said the students could live on or off-campus. Thanh lamented:

They didn't help us rent a house or suggest a house for us. [...] We had to do everything by ourselves.

These narratives suggest that before travelling these participants took living arrangement and the practicalities of everyday life (e.g., food, transport) for granted and may 
have been ill-prepared for challenges. It was as if they expected everyday living to be the same as what they had experienced at home.

Being poorly prepared contributed to the students' living arrangement issues and resulted in their feeling shocked and unable to cope with problems. They faced everyday living challenges while struggling to adjust to the new academic setting. The following section reports on the students' initial challenges.

\section{"People here didn't want to rent their flats out to students."}

The search for, and difficulties with accommodation featured in the major theme of challenging living arrangements and circumstances. The students arrived in New Zealand at a time when there was a shortage of rental accommodation and intense competitions for rentals. The students wondered if they were discriminated against. One student lamented that landlords did not want to rent to students.

There was a sense of desperation as the students needed a place to live in this new country and to be able to focus on their studies. Finding private accommodation was difficult for them as they did not know the options and were unfamiliar with New Zealand housing market, nor did they know anyone there who could help them:

Before leaving Vietnam, the students had found information on accommodation online that they could consider renting upon arrival. They wanted to view houses or other accommodation to make sure they met their needs. One student googled the distance to the university. Despite this, she felt the need to see the house in real life:

The only thing that made me exhausted was looking for a house. The first two weeks made me super tired. [...] But you didn't know if that place was near or far. Generally, you've never been here. Although you found some houses when still in Vietnam, and 
google the distance [to university, supermarket...], there are some differences [between reality and Google result]. (Lan)

Searching for accommodation was an exhausting and emotional experience for the students while trying to settle into their studies. Unable to find houses to rent, some booked temporary accommodation in backpackers' hostels. While this strategy was effective, it was not what they expected. For Bao, this was a hopeless journey because nobody wanted to rent their houses to her:

I felt I am small, insignificant, and marginalized. I mean I wasn't accepted. I felt hopeless because we couldn't rent a house during the first week, although we found some when in Vietnam and had arranged to view them. [...] People here didn't want to rent their flats to students. (Bao)

For financial reasons, none of the students lived in a university hall. One student did not want the rent to be 'a financial burden for her parents' (Thanh). University accommodation service was not regarded as useful by the students:

I think the service mainly focuses on students who wish to live in the halls. For those who want to live off-campus like us, like they just don't care. (Bao)

The information on the university's website about private accommodation was not of use to the students. They mainly found accommodation information through their networks or Trademe - a New Zealand online auction website.

Three of the students came to New Zealand together, which meant they had someone who understood them and helped with difficulties. This made them feel more secure. They wanted to stay together, at least for the first few months until they were familiar with the new environment. Thanh found it hard when she had to find her own accommodation: 
I felt alone in everything. We studied in the same program, came here together, and decided to stay together in the same flat. But why couldn't we do that? (Thanh)

\section{"When I was at home, I lived like a princess."}

In Vietnam, the students were middle-class professionals and often lived with their parents. Looking back, they recognized they had led privileged lives. Some struggled to live independently in New Zealand. Living "like a princess" in Vietnam, Thanh was aware she lacked skills (such as cooking) to lead an independent life. She arrived in New Zealand with her four Vietnamese classmates, hoping to live with them. They lived in a hostel for the first two weeks until Thanh left because they could not find a place big enough for all five. Suddenly, Thanh had to enter life for which she was not ready. During the first few weeks, she ate boiled eggs and vegetables and lost weight. Thanh recalled how she felt during the first few months in New Zealand:

When I lived away from my family, I had to do it all by myself. I was afraid, really afraid. [...] At home, I lived like a princess. I was afraid that I couldn't get through [this difficult period]. [Thanh]

Bao had a sense of insecurity when leaving her family and familiar friendship network. She contrasted her life in Vietnam and in New Zealand:

I have a feeling of insecurity. [...] In Vietnam, we had friends and family. Here, we have [Vietnamese] friends who study in the same program but are not really close friends like the ones in Vietnam. (Bao)

In Vietnam, Bao had a good job, the support of her extended family, her children, and close friends. This contributed to her desire to return home after completing her qualification. 


\section{"At least, we have someone to hold on to in an unfamiliar land."}

Spending time with Vietnamese friends, classmates, and flatmates made a difference to the students' lives. Some participants flatted with their co-national classmates, who provided advice or assistance with health issues.

When I am sick, my Vietnamese friend would give me some pills. She would also give me advice about what kinds of medicine I should take. (My)

The students provided solace to each other during times of homesickness which they all experienced:

When I am homesick, they encourage me to get through. We may watch a movie or do the cooking together to forget that feeling. (My)

Lan felt safe because her friends were with her during tough times:

At least, we have someone to hold on to in an unfamiliar land. (Lan)

Thanh was once hospitalized at mid-night, and her friends rallied around to care for her. One stayed with her that night despite a deadline for an assignment the following day. The friends knew that her family was not there and stayed with her until she was discharged. Thanh's situation might have got worse without her friends.

I felt lucky. [...] They took care of me carefully. I was there with no relatives around. It was fine for them to just leave me there and went home, but they didn't do that. I was grateful to them. (Thanh)

There was a strong bond between the students and their Vietnamese friends. Their relationship was established through spending time and having fun together:

We know each other better and can joke on everything, even sensitive topics. [...] In general, this helped me release stress. So, I want to have Vietnamese friends. (Bao) 
Vietnamese traditional holidays sometimes made the students feel homesick. In Vietnam, Tết (Lunar New Year festival) is a chance for family reunion. Hai felt lucky when living with a landlord originally from Vietnam, because he could enjoy the traditional dishes for Tết, which was unexpected to him:

We had bánh chung (square glutinous rice cake), bánh giò (pyramidal rice dumpling), and nem (fermented pork roll). It was like Tet in Vietnam. I felt like I was in Vietnam, not in a foreign country. (Hai)

For Hai, eating Vietnamese traditional dishes and having a decent Tết in New Zealand created a sense of family, or a sense of Vietnam right in New Zealand. However, this was for a brief time, as for much of his time he felt like a stranger in a foreign land.

\section{"I have to go to the library when I want to learn."}

Ideally, home is a place for refuge, security and where a person can relax and be themselves. Being in an unfamiliar country, the students knew that they had to save money for unexpected expenses. Therefore, they shared their flats or rooms with others, which meant they had limited space for study. The students considered the library as a good replacement for a learning space. While Bao found that studying at the library was common for students, she missed her spacious house in Vietnam.

I don't have the comfort of home here. My house [in Vietnam] was spacious and I had my own learning space. Everything. But in New Zealand, I am living in a small flat. I have to go to the library when I want to learn. There is almost no space to work at home. (Bao)

Bao added that the problem became serious when she had an assignment:

If there were three people, it would be alright. But because there are four of us, it becomes rather cramped. The living room is a bit small. Normally this is not a problem, 
but in exam periods, we have to go to the library. If one is cooking or talking on the phone, the others won't be able to study at all. (Bao)

Students need a quiet place to study, but a shared flat can be noisy. Hai usually spent his entire day at the library:

It wasn't quiet. So, when living in that house, I had to go to the library when I wanted to learn. [...] I ate my meals there. (Hai)

Limited living space also impacted on those who needed a space for personal conversations. Lan was busy working and studying during the day and could only ring her family in Vietnam late at night. However, at this time, her flatmates needed quiet, and even light voices at night might turn into a loud noise:

Midnight here is 6 pm in Vietnam. Yesterday, when I called home at that time, some of my flatmates got irritated. They knocked on my door, said the noise disturbed them, and asked me to keep my voice down. (Lan)

\section{"Everyone was having a party. It was almost impossible to study."}

Problems occurred between the students and their landlords and with flatmates. At one point, Thanh lived in a house with her landlady - a Vietnamese woman, and the landlady's husband - a New Zealander. The couple had problems, and inexplicably, the husband tried to involve Thanh in the arguments. She thought he might want to have 'an ally'. Thanh also had arguments with the husband. Being so upset with these problems, she could not sleep at night:

I was distressed. I came here to study. I had difficulties with my studies, which was enough for me. But I had additional problems with him, which made me feel tired. Sometimes I couldn't sleep, and I had to ring my friend at night. Sometimes I had to put on headphones to sleep, because they often quarreled at night. I was tired. (Thanh) 
Even co-national flatmates can have different priorities and senses of responsibility. Lan complained that her flatmates left the house in a mess in the exam period. She had to clean the house and wash the dishes by herself. However, she needed to work on her assignments too and could not do this all the time.

In assignment seasons, they don't clean the house. When I finish my assignment first, I do it. I always finish my assignment first, so I am the one who always cleans the house. But recently I have to work and study at the same time, so I was too tired to do the housework. I just washed my dishes, not other people's dishes. I even didn't cook for the whole week. I don't know if they felt uneasy about that. (Lan)

Living with people of various backgrounds and characters may create tensions. Hai's flatmates' lifestyles affected his life. During holiday times, they would drink beer and wine most days:

[The noise disturbs] my sleep, my life. They were having a holiday and didn't have any homework. They could spend the whole day drinking. Even on weekdays. They drank until 4 AM. [...] Everyone was having a party. It was impossible to study. (Hai)

Over time, he became accustomed to these problems and dealt with them in what could be seen to be a Vietnamese way. He was aware of the tension between his need for quiet to study and the flatmates desire to party through the night. Hai positioned his actions as respecting their needs through keeping his own emotions under control.

I was a hot-tempered person. But here, I need to keep my emotions under control. When I live with people from different countries, cultural differences emerge... I want to learn, but they are drinking, talking, or playing music. [These influence] my learning, my sleep. [In that situation,] some people may lose their temper, pick a quarrel, and have a bad relationship with them [who make noise]. (Hai) 
The Confucian emphasis on creating harmonious relationships could be seen in how the students responded to differences in lifestyles with their flatmates/room-mates. Hai did not judge his flatmates but worked out what he could do to create harmony, and persevered with his studies. While with time he became accustomed to the flatmates' behavior he eventually moved out.

\section{"There was not only me and another woman in the flat, but also a man"}

Differing cultural and social attitudes to gender and living arrangements were a source of stress. Female students were concerned about privacy in their flats. My could not lock her bedroom door because her landlord did not provide a key, which made her feel 'uneasy'. It was so 'strange' and 'weird' to her, because, in Vietnam, normally, male and female tenants would not live in the same flat. If that happened, the woman could always lock her room. Her parents in Vietnam were worried about this problem. Finally, she managed to find some way to lock her bedroom.

Because there was not only me and another woman in the flat, but also a man. I was worried. My family was worried about that too. Something could happen if the woman wasn't in the flat. Although everyone said that it was very safe in Wellington, I still keep my door locked whenever I was home alone, especially at night. (My)

Thanh's Vietnamese landlady entered Thanh's room when she was not home. Thanh thought this was a lack of respect for her privacy:

I share my room with another girl. Everything is OK. I mean she respects [my privacy]. But the landlady, who was Vietnamese, once opened my room door, thinking it was OK to do so when I was absent. (Thanh)

Although this issue negatively impacted on her study, Thanh did not confront the landlady to maintain a good relationship with her. She did not want to be disrespectful by 
expressing dissatisfaction with the landlady who was older than her. Besides, as a tenant, Thanh did not want to make the landlady, who was the authority in the house, upset. Later Thanh moved to a new house with flatmates who respected her privacy.

\section{"It's a shared flat, and I have to minimize my sky a little bit."}

In responding to a question about how to live with people with different personalities and backgrounds, the students repeatedly emphasized their desire for harmony amongst flatmates. They attempted to form or maintain a harmonious relationship with them and avoid conflicts by strongly focusing on self-control. They tried to change themselves rather than their flatmates' behaviors. The students thought they should control their own emotions and behaviors, as in Hai's response to his partying flatmates and again in Lan's response to her flatmates neglecting the housework:

It is easy to move mountains and rivers, but hard to change one's personality [A Vietnamese proverb]. [...] I adjust my personality. [In Vietnam], my house was my sky, but now it's a shared flat, and I have to minimize my sky a little. I don't change my personality, but I control it to fit in with my flatmates. (Lan)

At times, it was hard for the students to maintain their self-esteem and to keep their "self" in check. They described a readiness for changing themselves and caring more about other people's feelings than their own. Lan emphasized that people should not 'stick to their egos', and the ideal was to maintain good relationships:

I have strong character. [...] Sometimes I am inconsiderate or something. [...] Then I realized I had to re-arrange my time and consider [other people's needs], not just my own. I had to adjust myself to maintain a 'happy' relationship with my flatmates. [...] They also have to change themselves. I mean no one should stick to their egos. (Lan) 
Cultural differences may add to the difficulties. Hai quickly realized the difference in his food tastes and his flatmates'. However, wanting to interact with them, he ate Western dishes, although the flavor did not suit his tastes. Interestingly, once he realized his flatmates did not like the smell of fish sauce, which is usually used in Vietnamese dishes, he stopped cooking with it:

We may have different flavor and food preferences... You know, when making Vietnamese dishes, we often use fish sauce. But possibly they [my flatmates] can't stand the smell and feel uncomfortable. It [the smell] may hugely influence them. So, in this house, we have to be yielding and tolerant. (Hai)

Hai believed that not using fish sauce might be a way to avoid tension in the house. This showed his effort to build a good relationship with them. In this instance and in how he responded to their partying, he emphasized harmonious relations over his own needs.

\section{The essence of the living experiences of Vietnamese students in New Zealand}

One purpose of an IPA study is to discover the essence of participants' experiences of a phenomenon (Smith and Osborn 2008). The students described their living experiences as the two opposite sides of a coin: difficulties and chances for self-development. Whilst multiple factors influenced their daily lives such as the nature of their accommodation and how to maintain harmonious relationships with flatmates, things got better over time, and in the final interview round, the students talked about their experiences with an optimistic spirit, willingness to experience new things and face challenges. Drawing on their cultural values, they believed in their ability to overcome difficulties, knowing that there was always someone or something for them to 'hold on to' (e.g., friends and flatmates). 


\section{Discussion}

Previous research has highlighted the academic, language and psychological adjustment experiences of international students. The current study has deliberately explored the everyday living arrangements and experiences of a cohort of Vietnamese international students. Where one lives, which for these students was a temporary home, is ideally a place of refuge, security and where one can feel "at home". Home should be a place for international students to enjoy respite from the challenges of an alien academic and social environment.

The study's findings extend those observed in earlier studies on international students' experiences in different host countries. They echo findings from previous research in which participants had difficulties in finding affordable accommodation, and then with overcrowded accommodation impacted on the students' overall experiences (Marginson et al. 2010). Maslow (1954) highlighted the importance of having safe, secure and adequate accommodation to focus on higher needs such as education. My study contributes to the local and international literature by providing insights into the experiences of Vietnamese students and highlighting the role of accommodation and living arrangement in international students' experiences in host countries.

The research reported here was carried out prior to the COVID-19 (novel corona virus disease 2019) pandemic. Amid the crisis, the importance of accommodation became more apparent. International students were identified as among the most vulnerable groups during the pandemic ( $\underline{\text { Sahu 2020)}}$. At the time of publication, there were fears of recurring outbreaks of COVID-19 and of other such viruses. Overcrowded housing potentially makes it hard for those sharing accommodation and facilities during lockdown or in self-isolation, and may contribute to the spread of the disease within a house. Unlike local students, many international 
students are distant from their familiar networks and may be unable to return to their families for safe shelter or for assistance during such critical situations.

The results suggest that the students were not provided with adequate housing information, which impacted on their pre-arrival preparation and housing experiences in New Zealand. This result further supports findings from previous research on the importance of access to information about the prospective. Pre-departure preparation may come in the form of a pre-departure curriculum designed to ease the intercultural transition of students in their studies and life in another country (Lamberton and Ashton-Hay 2015). A study on the supports that international students in England and the Netherlands needed found that students appreciated pre-arrival contact with peers, and information on accommodation (Bartram 2008). At the same time, students should be encouraged to actively research conditions in the new country and to seek guidance from co-nationals who have studied in the host country.

The study illustrates issues related to the students' living experiences and arrangements, relationships with flatmates and the challenges of being independent. Such issues impacted the students' study and socio-cultural experiences. The students' personal agency and cultural identity could be seen in their attitudes towards and responses to emerging problems. Whilst facing issues, and at times feeling hopeless, they still overcame difficulties. This is consistent with other research with a focus on the agency of international students (Nguyen and Pennycook 2018; Marginson 2014). These students demonstrated a strong desire for harmonious relationships with their flatmates by being tolerant and avoiding conflicts and tensions.

Whilst acceptance and respect for cultural differences are part of cultural inclusiveness within international higher education settings (McLoughlin 2001) and, in this study, may come from the students' current education experiences in New Zealand, they could be regarded 
as a trait of collectivistic cultures and Vietnamese culture in particular (Leung et al. 1992). In those cultures, relationships with other members of a group or a community play a central role. Traditional Vietnamese culture with a blend of Confucian and Buddhist values emphasizes the role of harmony and tolerance in relationships amongst people (Nguyen 2016). One student was pleased that he could celebrate Lunar New Year and have Vietnamese traditional dishes. A Vietnamese folksong says: "Dù ai buôn bán nơi đâu. Nhớ đến ngày Tết rủ nhau mà về", (Wherever in the world you are conducting business. Remember to remind each other to return home for Tet celebration) denoting the significance of this festival deep-rooted in the minds of the Vietnamese. Those cultural factors have shaped the students' cultural identity and influenced their attitudes and interactional strategies in daily life.

Whilst there were commonalities in the students' experiences, there was a suggestion of gender differences in experiences. For example, whilst the four females highlighted emotional issues and the need to have someone to share their feelings with, the male students did not but focussed on problems when flatting with people of different nationalities. Such differences are in agreement with earlier studies which showed that female students may encounter different difficulties than their male counterparts (Carballo 1994; Le 2011). The main purpose of highlighting such findings is to demonstrate the complexities of the experiences of different genders rather than to portray the female students as emotional or dependent people. These findings could help support services and those who are concerned about the experiences of international students more aware of the students' potential issues and provide appropriate assistance. Although I cannot draw too much from such a small sample with only one male, gender appears to play a role in the experiences of these students. Future research could explore the role gender plays in students' experiences. 
The students' friendship networks mainly comprised Vietnamese people, except for the male student who established good relationships with flatmates from other countries. All the students kept in close contact with their families in Vietnam. Their families and co-national friends helped reduce the feeling of loneliness and provided necessary assistance. Maintaining connections with family and home culture has been shown to allow the students to strengthen 'the continuity of self' and sustain a sense of self (Marginson et al. 2010; Tran and Gomes 2017). Despite such benefits, the students reported that their co-national networks may limit their use of English in daily communication and their contact with local culture, which suggests disconnectedness with the local community.

\section{Implications and limitations}

The study reveals that Vietnamese students face difficulties in relation to living arrangements. In the context where local and international students are challenged in finding suitable accommodation, institutions ideally would provide greater help in navigating the local housing market and securing accommodation. With these Vietnamese students, it appeared that the institution provided cursory information and left the students to find accommodation.

It may be beneficial for students if universities can find out what support and pre-arrival assistance they need, help to find suitable accommodation, and make housing information accessible and related to students' needs. Universities may consider taking measures to increase the availability of affordable quality accommodation.

For the Vietnamese students in this study, living with people outside of their families and dealing with landlords/landladies were new and challenging experiences. Other international students may have similar experiences. Universities could consider providing students with practical tips on how to get along with their flatmates and to negotiate with others such as landlords. 
The participants of this study were Vietnamese students living in private accommodation, which restricts the study' possibility to reflect the living experiences of the wider international student population. My recommendations for future studies would be to employ a different research design (e.g., survey or mixed methods), using a larger sample of international students lodging in other types of accommodation and coming from other countries, looking at how they deal with housing-related issues.

\section{Conclusions}

In line with studies about the experiences of international students in general and Vietnamese international students in particular, this study demonstrates issues that Vietnamese students may encounter when pursuing further education in another country. Students' attitudes and behaviours are shaped by familial and cultural factors. This study has shown how accommodation and living arrangements impacted powerfully on this group of Vietnamese students' experience of studying overseas. These findings not only contribute insights into the living experiences of international students, but also provide information for developing programs and materials to enhance their experiences.

\section{Acknowledgements}

I would like to thank Dr Stephanie Doyle and Professor Joanna Kidman from the School of Education, Victoria University of Wellington for their insightful feedback and comments on this paper, and the Vietnamese students who participated in this study. 


\section{References}

An, S., Lim, S. S., Lee, H. and Pham, B. (2018), 'Overcoming prejudice, seeking support: Transnational social media communication of female Vietnamese students in South Korea and Singapore', Transitions: Journal of Transient Migration, 2:2, pp. 107-126.

Arkoudis, S., Dollinger, M., Baik, C. and Patience, A. (2019), 'International students' experience in Australian higher education: Can we do better?', Higher Education, 77:5, pp. $799-813$

Australian Education International. (2020), 'Monthly summary of international student data Australia - March 2020', https://internationaleducation.gov.au/research/International-StudentData/Documents/MONTHLY\%20SUMMARIES/2020/Mar\%202020\%20MonthlyInfographi c.pdf. Accessed 3 June 2020.

Bartram, B. (2008), 'Supporting international students in higher education: Constructions, cultures and clashes', Teaching in Higher Education, 13:6, pp. 657-668.

Berry, J. W. (2006), 'Stress perspectives on acculturation' in Sam, D. L. and Berry, J. W., eds., The Cambridge Handbook of Acculturation Psychology, Cambridge: Cambridge University Press, pp. 43-57.

Bui, T. A. (2020), 'Becoming an intercultural doctoral student: Negotiating cultural differences', Journal of International Students, 11:1. 
Calder, M. J., Richter, S., Mao, Y., Burns, K. K., Mogale, R. S. and Danko, M. (2016), 'International students attending Canadian universities: Their experiences with housing, finances, and other issues', The Canadian Journal of Higher Education, 46:2, pp. 92-110.

Campbell, N. (2012), 'Promoting intercultural contact on campus: A project to connect and engage international and host students', Journal of Studies in International Education, 16:3, pp. 205-227.

Carballo, M. (1994), Scientific Consultation on the Social and Health Impact of Migration: Priorities of Research, Geneva: International Organization for Migration.

Ding, Q. and Devine, N. (2018), 'Exploring the supervision experiences of Chinese overseas Phd students in New Zealand', Knowledge Cultures, 6:1, pp. 62-78.

Education New Zealand (2018), 'New Zealand - Vietnam strategic engagement plan on education', https://enz.govt.nz/assets/Uploads/New-Zealand-Viet-Nam-StrategicEngagement-Plan-on-Education-dated-20-February-2018.pdf/. Accessed 20 February 2019.

Fabricius, A. and Preisler, B. (2015), Transcultural Interaction and Linguistic Diversity in Higher Education: The Student Experience, Basingstoke: Palgrave Macmillan. 
Franken, M. (2013), 'Significant knowledge transitions and resituation challenges in becoming a researcher: International scholarship students' perspectives', International Journal for Researcher Development, 4:2, pp. 86-102.

Institute of Intenational Education. (2020), 'Project atlas - America', https://www.iie.org/Research-and-Insights/Project-Atlas/Explore-Data/United-States. Accessed 3 June 2020.

Institute of International Education. (2020a), 'Project atlas - Canada', https://www.iie.org/Research-and-Insights/Project-Atlas/Explore-Data/Canada. Accessed 3 June 2020.

Institute of International Education. (2020b), 'Project atlas - New Zealand', https://www.iie.org/Research-and-Insights/Project-Atlas/Explore-Data/New-Zealand. Accessed 3 June 2020.

Khawaja, N. G. and Stallman, H. M. (2011), 'Understanding the coping strategies of international students: A qualitative approach', Australian Journal of Guidance and Counselling, 21:2, pp. 203-224.

Lamberton, G. and Ashton-Hay, S. (2015), 'Preparing Chinese international business students for the transition to undergraduate study in Australia', 14:2, pp. 155-171.

Lazarus, R. S. (1997), 'Acculturation isn't everything', Applied Psychology, 46:1, pp. 39-43. 
Le, A. (2014), 'Vietnamese international student repatriates: An exploratory study', Ph.D disseration, Lincoln: University of Nebraska.

Le, N. T. (2011), 'Holding on to Vietnam: Motivation and the acculturation experience of Vietnamese international students in Australia', Ph.D. dissertation, Australia: University of New South Wales.

Leung, K., Au, Y.-F., Fernández-Dols, J. M. and Iwawaki, S. (1992), 'Preference for methods of conflict processing in two collectivist cultures', International Journal of Psychology, 27:2, pp. 195-209.

Li, B. D. (1993), 'A brief overview of sino-western exchange: past and present' in R. Hayhoe et al. (eds), Knowledge Across Cultures: Universities East and West, Toronto, Canada: OISE Press, pp. 301-308.

Lillyman, S. and Bennett, C. (2014), 'Providing a positive learning experience for international students studying at UK universities: A literature review', Journal of Research in International Education, 13:1, pp. 63-75.

Long, L. D. (2014), 'Does it matter where college students live? Differences in satisfaction and outcomes as a function of students' living arrangement and gender', The Journal of College and University Student Housing, 40:2, pp. 66-85. 
Marginson, S. (2014), 'Student self-formation in international education', Journal of Studies in International Education, 18:1, pp. 6-22.

Marginson, S., Nyland, C., Sawir, E. and Forbes-Mewett, H. (2010), International Student Security, Cambridge: Cambridge University Press.

Maslow, A. H. (1954), Motivation and Personality, New York: Harper \& Row.

Matthews, J. (2000), 'Violent visions and speechless days: Corporeality and the politics of image' in I. Ang, S. Chalmers, L. Law and M. Thomas (eds), Alter/Asians: Asian-Australian Identities in Art, Media and Popular Culture, Annandale: Pluto Press.

McLoughlin, C. (2001), 'Inclusivity and alignment: Principles of pedagogy, task and assessment design for effective cross-cultural online learning', Distance Education, 22:1, pp. 7-29.

Montgomery, C. (2010), Understanding the International Student Experience, New York: Palgrave Macmillan.

Najib, N. U. M., Yusof, N. A. and Osman, Z. (2011), 'The relationship between students' socio-economic backgrounds and student residential satisfaction', World Academy of Science, Engineering Technology, 5:8, pp. 1200-1205. 
Nguyen, B. T. T. and Pennycook, A. (2018), 'Dancing, Google and fish sauce: Vietnamese students coping with Australian universities', Asia Pacific Journal of Education, 38:4, pp. 116.

Nguyen, M. N. and Robertson, M. J. (2020), 'International students enacting agency in their PhD journey', Teaching in Higher Education, pp. 1-17. doi:10.1080/13562517.2020.1747423

Nguyen, Q. and Buckingham, L. (2019), 'Source-use expectations in assignments: The perceptions and practices of Vietnamese master's students', English for Specific Purposes, 53, pp. $90-103$.

Nguyen, Q. T. N. (2016), 'The Vietnamese values system: A blend of Oriental, Western and Socialist values', International Education Studies, 9:12, pp. 32-40.

Pham, H. H. (2018), 'International students' choice of destinations for overseas study: A specific push-pull model for Vietnam' in L. T. Tran and S. Marginson (eds), Internationalization in Vietnamese Higher Education, Dordrecht: Springer.

Pham, L. and Saltmarsh, D. (2013), 'International students' identities in a globalized world: Narratives from Vietnam', Journal of Research in International Education, 12:2, pp. 129141. 
Rinne, T. and Fairweather, J. (2011), An international comparison of models of cultural and national identity and their implications for New Zealand innovation, New Zealand: Lincoln University.

Sahu, P. (2020), 'Closure of universities due to Coronavirus Disease 2019 (COVID-19): Impact on education and mental health of students and academic staff', Cureus, 12:4, pp. 1-6.

Sawir, E., Marginson, S., Deumert, A., Nyland, C. and Ramia, G. (2008), 'Loneliness and international students: An Australian study', Journal of Studies in International Education, 12:2, pp. 148-180.

Sawir, E., Marginson, S., Forbes-Mewett, H., Nyland, C. and Ramia, G. (2012), 'International student security and English language proficiency', Journal of Studies in International Education, 16:5, pp. 434-454.

Schartner, A. (2016), 'The effect of study abroad on intercultural competence: a longitudinal case study of international postgraduate students at a British university', Journal of Multilingual and Multicultural Development, 37:4, pp. 402-418.

Schunk, D. H. (2012), Learning Theories: An Educational Perspective, 6th ed., Boston: Pearson.

Schunk, D. H., Meece, J. R. and Pintrich, P. R. (2012), Motivation in Education: Theory, Research, and Applications, New York: Pearson Higher Ed. 
Smith, J. A., Flowers, P. and Larkin, M. (2009), Interpretative Phenomenological Analysis:

Theory, Method and Research, Thousand Oaks, CA: Sage.

Smith, J. A. and Osborn, M. (2008), 'Interpretative phenomenological analysis' in J. A. Smith (ed), Qualitative Psychology: A Practical Guide to Research Methods, London: Sage, pp. 5380.

Tran, L. T. (2011), 'Committed, face-value, hybrid or mutual adaptation? The experiences of international students in Australian higher education', Educational Review, 63:1, pp. 79-94.

Tran, L. T. and Gomes, C. (2017), International student connectedness and identity, Singapore: Springer.

Triandis, H. C. (1997), 'Where is culture in the acculturation model?', Applied Psychology, 46:1, pp. 55-58.

Vu, H. T. and Doyle, S. (2014), 'Across borders and across cultures: Vietnamese students' positioning of teachers in a university twinning programme', Journal of Education for Teaching, 40:3, pp. 267-283.

Ward, C., Bochner, S. and Furnham, A. (2001), The Psychology of Culture Shock, 2nd ed., Hove: Routledge. 
Ward, C. and Geeraert, N. (2016), 'Advancing acculturation theory and research: The acculturation process in its ecological context', Current Opinion in Psychology, 8, pp. 98-104.

Watkins, D. A. and Biggs, J. B. (2001), Teaching the Chinese learner: Psychological and pedagogical perspectives, Hong Kong: CERC and ACER.

World Health Organization (2013), 'Health impact assessment (HIA): The determinants of health', https://www.who.int/hia/evidence/doh/en/. Accessed 16 January 2019.

Wright, C. and Schartner, A. (2013), 'I can't... I won't?'International students at the threshold of social interaction', Journal of Research in International Education, 12:2, pp. 113-128.

Zhang, X. (2018), 'Chinese international students in New Zealand: Views of citizenship and democracy', Citizenship Teaching \& Learning, 13:2, pp. 241-252.

\section{Contributor details}

Hau Trung Ho is a PhD student at the School of Education, Victoria University of Wellington, New Zealand

Contact: Victoria University of Wellington, Faculty of Education, Level 8, Murphy Building, Kelburn Parade, Kelburn, Wellington 6140

Email: hau.trungho@vuw.ac.nz 